\title{
The Icaiche Formation: Major contributor to the stratigraphy, hydrogeochemistry and geomorphology of the northern Yucatán Peninsula, Mexico
}

\author{
Eugene C. Perry, Gudalupe Velazquez-Oliman, Rosa M. Leal-Bautista, Nicholas P. Dunning
}

Eugene C. Perry

Northern Illinois University, Geology and Environmental Geosciences, Emeritus, DeKalb, Illinois 60115 , USA

\section{Gudalupe Velazquez-Oliman}

Centro de Innovación e Investigación para el Desarrollo Sustentable, Javier Rojo Gómez, Mza. 9, Lote 1, Local F, Puerto Morelos, Quintana Roo. C.P. 77580, Mexico.

\section{Rosa M. Leal-Bautista}

rleal@cicy.mx

Centro de Investigación Científica de Yucatán, A.C., Unidad de Ciencias del Agua, Calle 8, No. 39, Mza. 29, SM 64, Cancún, Quintana Roo C.P. 77524, Mexico.

\section{Nicholas P. Dunning}

University of Cincinnati, Geography Department, 401 Braunstein Hall, 2600 Clifton Ave. Cincinnati, OH, 45221, USA

BOL. SOC. GEOL. MEX. 2019

VOL. 71 NO. 3

P. $741-760$

http://dx.doi.org/10.18268/BSGM2019v7 ln3a7

Manuscript received: June 18, 2018.

Corrected manuscript received: October 30, 2018.

Manuscript accepted: November 11, 2018.

\section{ABSTRACT}

The Paleogene-Eocene Icaiche Formation, which contains bedded gypsum deposits that cover an estimated minimum area of $10000 \mathrm{~km}^{2}$, is located in the southern parts of the Mexican states Yucatan, Campeche and Quintana Roo. The formation has been little studied because it crops out in an area with limited access, few people, and little economic activity. Low population density is a consequence of the sulfate-contaminated water that is produced during weathering and dissolution of the gypsum deposits in the formation. The Icaiche Formation occupies a considerable part of the physiographic area known as the Elevated Interior Region (EIR) of the Yucatán Peninsula, which encompasses a terrain that the Maya occupied with varying success for almost two millennia and finally almost completely abandoned by about 950 CE. During their tenure, the Maya survived and at times prospered in this region of unpalatable groundwater by using and adapting natural depressions (called bajos) for water supply and, somewhat later, by using abundant impermeable local clays in construction of dams and ingenious systems for water storage and transport. Because of the relatively high solubility of gypsum, the Icaiche Formation has had an outsize influence on hydrologic and geomorphic features and groundwater geochemistry beyond where it crops out and into parts of the Yucatán Peninsula where it is present in the subsurface, particularly those places where it encounters flowing groundwater. In this study, we propose that gypsum dissolution, followed by collapse of overlying rock, was important in: 1) the formation of poljes (large, partly or completely enclosed karst basins with flat floors and interior drainage) along the east and west margins of the EIR; 2) the development of deep karst in north central Yucatán state; and 3) the formation of irregular terrains, extensive brecciation of rock, and highly varying water quality in the area at the eastern margin of the EIR (between Lake Chichancanab and Felipe Carrillo Puerto, Quintana Roo). Argillaceous sediment released during weathering of the Icaiche Formation, perhaps mixed with siliceous components of impact deposits from the Chicxulub Impact may have affected the permeability of post-Eocene marine sedimentary rocks, perhaps including local facie of the Carrillo Puerto Formation, formed on the southeast margin of the Peninsula. The resulting rocks have markedly lower permeability than rock of the more northerly lowlands of the Mexican portion of the Yucatán Peninsula that host a pervasive fresh water lens overlying a saline intrusion.

Keywords: Yucatan Peninsula, gypsum, stratigraphy, hydrogeochemistry, karst.

\section{RESUMEN}

La Formación Icaiche Paleoceno-Eoceno aflora en la zona sur de los estados mexicanos de Tucatán, Campeche y Quintana Roo. Abarca más de $10000 \mathrm{~km}^{2}$ y se caracteriza por capas de depósitos de yeso. Esta formación ha sido poco estudiada ya que el afloramiento se presenta en un área con limitado acceso, limitada población y reducida actividad económica. Estas circunstancias están directamente relacionadas con la presencia de sulfato disuelto en el agua subterránea, consecuencia de la erosión y disolución de los depósitos de yeso de la Formación que afectan las condiciones químicas del agua útil, generando poco interés de la población por establecerse en esta zona. La Formación Icaiche ocupa una zona considerable del área fisiográfica conocida como Región Interior Elevada (Elevated Interior Region [EIR]) de la Península de Tucatán, la cual incluve terrenos ocupados por los Mavas, con cierto éxito por casi dos mil años y que fueron finalmente abandonados para el 950 CE. Estudios arqueológicos han señalado que las condiciones de apogeo en esta región se dieron cuando los mayas usaron y adaptaron las depresiones kársticas de la zona, denominadas "bajos", como los principales suministros de agua. Incluso el aprovechamiento de los sedimentos arcillosos de la zona permitió la construcción de sistemas de almacenamiento y de transporte del agua. Sin embargo, esto no fue constante debido a la alta solubilidad del yeso que predomina en los afloramientos de la Formación Icaiche. Esta formación tiene influencia en las características de permeabilidad de la zona y en las características hidrogeológicas y geomorfológicas tanto en superficie como en las secciones no afloradas de la Formación. Sin embargo, su importancia no ha sido reconocida ni la hidrogeoquímica que puede presentar los flujos subterráneos en la Península de Tucatán. En este trabajo se propone que la disolución del sulfato de calcio (yeso) seguida por los procesos de colapsos kársticos generaron: 1) la formación de poljes (depresiones kársticas elongadas que se presentan como valles cerrados) que aparecen en las márgenes este y oeste de la EIR; 2) la formación de geoformas kársticas profundas que se presentan en la zona norte-central del estado de Yucatán; y 3) la formación de las irregularidades (extensive brecciation of rock), así como la variación hidrogeoquímica de los flujos subterráneos en la margen este de la EIR (entre Lago Chicancanab y la Formación Felipe Carrillo Puerto en Quintana Roo. Asi mismo, se sugiere que los sedimentos arcillosos formados durante los procesos de erosión de la Formación Icaiche y su posible mezcla con depósitos de sílice del impacto del Chixchulub pudieron afectar la permeabilidad de las rocas sedimentarias de origen marino del post-Eoceno, posiblemente incluyendo las facies locales de la Formación Felipe Carrillo Puerto que se presentan en el margen sureste de la Península. Lo anterior resultó en un material con baja permeabilidad para la zona sur de la parte mexicana de la península de Tucatán comparada con la zona norte cuya permeabilidad permite la presencia del lente de agua dulce que se superpone a la intrusión salina.

Palabras clave: Península de Yucatán, yeso, estratigrafía, hidrogeoquímica, carst. 


\section{Introduction}

The little-studied Icaiche Formation crops out in southern Campeche, southern Quintana Roo, and southernmost Yucatán state, Mexico. It is worth noting that rocks equivalent or similar to those of the Icaiche Formation exist in northern Guatemala and northern Belize, but these have not been formally correlated.

This paper examines ways in which gypsum and probably argillaceous material of that formation may have exerted an outsize influence on the present hydrogeology and geomorphology of the Mexican portion of the Yucatán Peninsula, including all parts of the three states where the Icaiche Formation is present either at the surface or in the subsurface (Figure 1). This inclusive region is henceforth referred to simply as "Yucatán" unless that word is qualified to indicate the state of Yucatán. Exposure of Icaiche Formation rocks is sparse, and the contact relations with other formations (Figure 1) are incompletely known because of thick tropical vegetation, intense weathering, and limited road access. Furthermore, gypsum abundance can be obscured because its dissolution can produce a blanket of unconsolidated overburden by release of insoluble interbedded argillite. Abundant gypsum can contribute to especially rapid weathering in areas of moderate to high precipitation like southern Yucatán, where average annual rainfall is 1100-1600 mm/year (Dunning et al., 2012; Dunning et al., 2016). This enhanced weathering occurs because, the solubility of gypsum is several times greater than that of calcite, except at low $\mathrm{pH}$.

\section{Stratigraphic relations in the part of the Yucatán Peninsula within Mexico}

\subsection{THE ICAICHE FORMATION AND ITS GYPSUM MEMBER}

The stratigraphic framework for Yucatán geology was established by Jacques Butterlin and Federico
Bonet who made an extensive field study of the area between 1958 and 1960 (Butterlin and Bonet, 1960). Lacking identifiable fossils for correlation, they used the presence of bedded evaporite as the defining characteristic of the Icaiche Formation. The importance of this characteristic will be emphasized here. The outcrop boundaries of the Icaiche Formation within Mexico, shown in Figure 1, conform to those in the map of the Estados de Campeche, Quintana Roo y Yucatán, 2007 (SGM, 2017). Note that it is probable that Icaiche rocks continue south into Belize and Guatemala (Flores, 1952).

The Icaiche Formation consists of Paleocene-lower Eocene lagoonal rocks whose detailed stratigraphy is indeterminate because recrystallization has made fossil correlation difficult. Despite poor exposure, it is possible to use the quarry symbols on the map of SGM (2017) to define an outcrop area of about $10000 \mathrm{~km}^{2}$, which is centered on Xpujil, Campeche to approximate the minimum area of surface exposure of Paleocene-Eocene bedded gypsum within Yucatán. This area is shown by the rectangle labelled "Outcrop Area of Gypsum Member" in Figure 1. We shall refer to these gypsum beds informally as the gypsum member (GM) of the Icaiche Formation. In the region where it is exposed in outcrop, the GM has an estimated minimum thickness of at least 25-35 $\mathrm{m}$ as discussed below. Figure 2 is a generalized stratigraphic column that includes the rocks discussed in this paper.

\subsection{GRETAGEOUS BARTON GREEK FORMATION AND BASAL PALEOGENE ALBION FORMATION}

In Yucatán, the Icaiche Formation is underlain by two older formations: 1) the Barton Creek formation part of the Yucatán Group of Upper Cretaceous shallow carbonates and evaporites (Viniegra-O., 1981; Peterson, 1983) and 2) the transitional Cretaceous-Paleogene Albion Formation, consisting of a thin blanket of partially cemented air-fall material from the terminal Cretaceous Chicxulub bolide impact that rests 


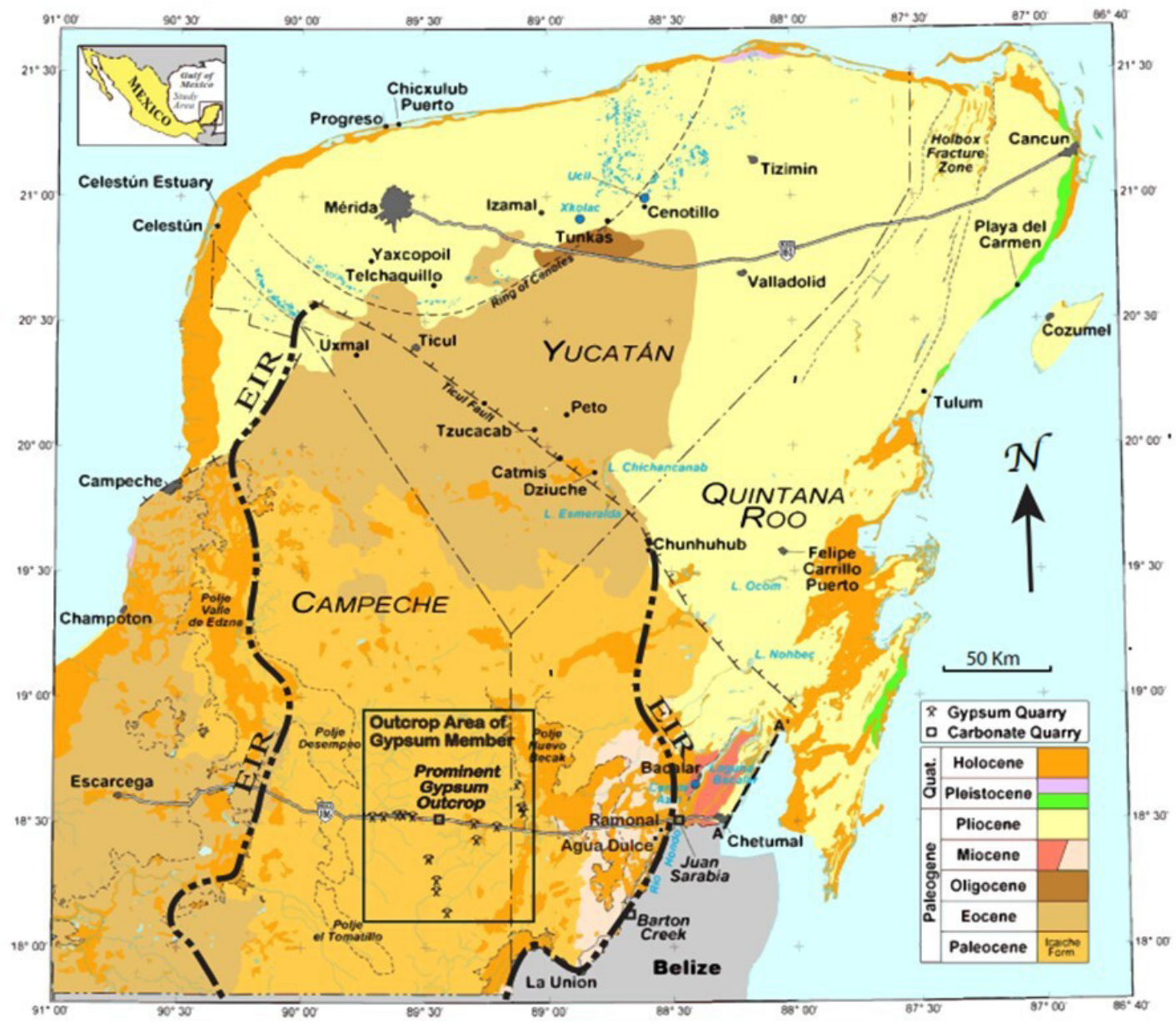

Figure 1 Geological Map of the Mexican Yucatán Peninsula (modified from SGM, 2017).

disconformably atop a highly weathered surface of Barton Creek formation dolomite (Pope et al., 2005). A single contact of the Albion Formation with weathered, white, micritic Paleogene dolomite overlying pink and tan, thin-bedded, micritic limestone has been identified by Pope et al. (2005) at Agua Dulce (Figure 1), but that Paleogene unit has not been definitively correlated with the Icaiche Formation.

Exposure of the Barton Creek formation in the study area (and thus in Mexico) consists of only two outcrops (Pope et al., 2005). The largest of these includes the Johnson quarry $\left(18.516^{\circ} \mathrm{N}\right.$, $88.485^{\circ} \mathrm{W}$ ), about $20 \mathrm{~km}$ west of Chetumal in a block uplifted along the Río Hondo Fault (Figure 1). The other exposure, near Ramonal (Figure 1) is a small outcrop beneath weakly consolidated
Albion Formation rocks. Although small, this outcrop is significant because it clearly shows that the upper surface of the Barton Creek formation is strongly altered "deeply weathered [...] dolomite with iron oxide staining, calcite veins, and abundant solution cavities" (Pope et al., 2005). The Albion Formation is exposed in numerous other places along the Ucum-Álvaro Obregón highway (which parallels the Río Hondo Fault and the coincident Belize border) (Pope et al., 2005). Thus, the Barton Creek formation can also be inferred to be present at shallow depth along the highway. A large additional outcrop of both the Barton Creek formation and the Albion Formation occurs along the projection of the Río Hondo Fault at the Albion Island quarry in Belize (labeled Barton Creek in Figure 1) (Pope et al., 2005). 


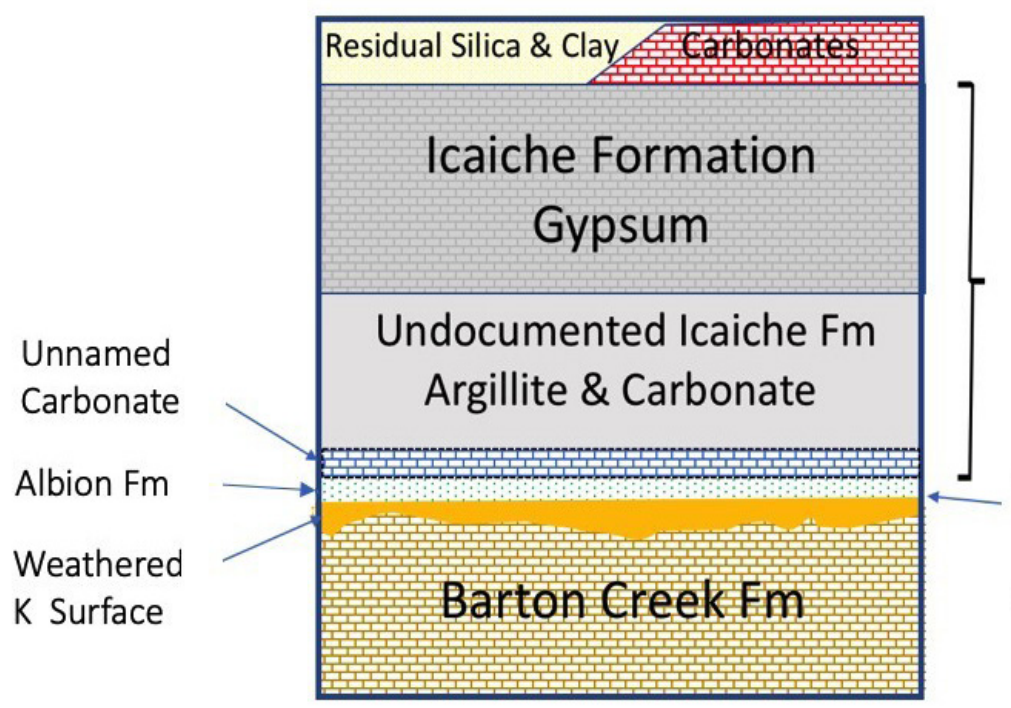

Post Eocene

Paleocene-

Eocene

Cretaceous-

Paleogene

Cretaceous

Figure 2 A generalized stratigraphic column that includes the rocks discussed in this paper.

\subsection{ICAICHE FORMATION STRUGTURE AND OVERLYING ROGKS}

The Icaiche Formation forms part of an anticline that plunges gently to the north. The Formation crops out over much of southern Campeche and southwestern Quintana Roo; however, in the state of Yucatán the Icaiche Formation is present almost entirely in the subsurface; it crops out on the surface only in the southernmost part of the state (Figure 1).

On the north, east, and west of its main area of outcrop, the Icaiche Formation is overlain directly by the Eocene Chichen Itza Formation, by the Pliocene Carrillo Puerto Formation, by bits of Miocene rocks, and by alluvium mapped as Quaternary. Even where no unconsolidated material is mapped, the Icaiche Formation is blanketed by a variably thick layer of soil and smectitic clay that may be both a residuum of the formation and the product of gradual aeolian deposition that has contributed parent material to the soil cover across the Peninsula throughout the Quaternary. Sources for the latter material include ash from various Central American and Mexican volcanoes, Saharan dust, and North American loess (Sedov et. al., 2008, Cabadas-Baez et al., 2010; Bautista et al., 2011; Tankersley et al., 2015, 2016).

\subsection{CORRESPONDENGE OF THE IGAIGHE OUTGROP AREA TO THE ELEVATED INTERIOR REGION OF THE MAYA LOWLANDS}

The area over which the Icaiche Formation crops out ranges in elevation from about 50 to $300 \mathrm{~m}$ above mean sea level (msl) and is included within a somewhat larger physiographic region referred to as the Elevated Interior Region (EIR) of the Maya Lowlands (Dunning et al., 2012). The EIR marks an area in which practical reasons related to geology and soil types dictated a distinctive Maya style of agriculture and water management that is, in many cases, closely related to the outcrop or shallow subcrop pattern of the Icaiche Formation (Figure 1). Therefore, for convenience, we will adopt the term EIR to designate the major region of focus for this study. We do this in part to emphasize the unusually clever adaptation here by humans to constraints imposed by regional geology. From the perspective of human occupation, the geologic features that most readily distinguish the EIR from northern Yucatán are the "abundance of soil and of gypsum over much of the area" (Gunn et al., 2002), "and the absence of an accessible fresh water lens in hydraulic equilibrium with the ocean" (Perry et al., 2011). These features combined to create, in the EIR, a harsh land, 
whose soil, although arable, is easily poisoned by water contaminated with sulfate derived from dissolving gypsum. A further problem for farming arises from wide variation in precipitation that can alternately flood and desiccate fields. Despite this bad groundwater and variable climate, the Maya survived and sometimes prospered in this environment for nearly two millennia - between $1000 \mathrm{BCE}$ and about $925 \mathrm{CE}$, from the Middle Preclassic to Late Terminal Classic periods (Castellanos and Foias, 2017). These environmental challenges arguably were a driving force behind ancient urbanization in the EIR, as populations organized to meet collective water management needs (Dunning et al., 2016). By about 950 CE the Maya left and did not return except around areas with perennial water supplies (Dunning et al., 2012; Beach et al., 2015a).

As discussed further in Section 5.1, although the fit between geology and Maya culture and technology developed in the EIR is imperfect, it is about as good as is possible to determine given our present state of geologic/hydrologic knowledge. This limiting knowledge is illustrated by reference to figure 1 of a review paper by Beach et al. (2015a) that outlines some 16 geomorphic sub-regions within the states of Yucatán, Campeche, and Quintana Roo. Of these regions, only sub-region 7, encompassing the Puuc cities Uxmal and Sayil (section 5.1) and sub-region 10, a polje (section 4.3), fall comfortably into environmental patterns for which we can currently offer specific limiting geologic/hydrologic explanations.

\section{Discussion}

\subsection{IMPORTANGE OF GYPSUM AND ARGILLITE IN THE ELEVATED INTERIOR REGION TO GEOMORPHOLOGY AND HUMAN ACTIVITY}

Despite the paucity of geological information about the EIR, we think the knowledge available is adequate to draw useful inferences about how the geology of its rocks, especially the Icaiche formation, have influenced the geomorphology and hydrogeology of the Peninsula. Furthermore, we hope this study will provide some general insight into the importance that gypsum and interbedded argillite can have in forming landscapes under varying conditions of weathering. Because available data are limited, our conclusions will necessarily be tentative but may be useful for further investigation. We will draw on several observations: 1) the extensive size and thickness of the GM; 2) the definitive evidence provided by systems of water storage, successfully used in Classical Maya times, that required a thick residual cover of impermeable argillaceous clay (much greater than what is present in the northern lowlands); 3) the qualitative outcrop information about the abundance of argillaceous material in the Icaiche Formation. 4) the knowledge from drill core (Lefticariu et al., 2006) that weakly consolidated Albion Formation impact ejecta containing a significant quantity of devitrified glass (Pope et al, 2005) underlies the Icaiche formation; 5) the distinctive mapped patterns of interior drainage systems that are labeled poljes on the SGM (2017) (Perry et al., 2009; Perry et al., 2011); 6) the distinctive karst forms present near the northern Peninsular coast in Yucatán state that are consistent with dissolution of deeply buried gypsum (Socki et al., 2002; Perry et al., 2009); and 7) the facies changes in younger rocks of eastern Quintana Roo, possibly related to transport of argillaceous sediment to the coast (Leal-Bautista and Cejudo, 2017).

EIR agriculture depended on abundant impermeable clay required by Mayas of Classical times to construct extensive systems of canals, dams, and reservoirs to compensate for absence throughout the region of reliable sources of potable groundwater (Matheny, 1976; Matheny et al., 1983; Gunn et al., 2002; Domínguez and Folan, 1996; Dunning et al., 2012; Beach et al., 2017; Dunning et al., 2016). Abundant layers of clay in the region also serve as natural aquitards for shallow perched lakes such as Lake Silvituk (Perry et al., 2011). There are probably multiple sources for this surficial clay as mentioned in section 2.2. Much probably came, at least directly, from weathering of local bedrock, 
but, whereas bedrock over most of the area is the Icaiche Formation, the northwest corner, including important archeological sites such as Uxmal, are located on the Eocene Chichen Itza Formation (section 5.1).

One argument suggesting that the Icaiche Formation is an important source of surficial clay in the region (and perhaps the ultimate primary source) is that the pervasive saline intrusion penetrates only slightly south of the northern fringes of the EIR (Perry et al., 2009; Perry et al., 2011), as discussed further in section 5. This indicates that carbonates of the Icaiche Formation are significantly less permeable than the carbonate rocks of the north, presumably as a result of increased argillite content. Another possible argillite source is siliceous material both within and beneath the GM, as discussed in section 3.3.

\subsection{MORE ACTIVE WHEN WET: INTERACTION OF GYPSUM WITH GROUNDWATER}

To advance our suggestion that the GM has had a disproportionate influence on the surface geological processes in Yucatán, we shall first present evidence that bedded gypsum is continuous in the subsurface to the north of the present area of outcrop (all the way to the north coast of Yucatán state) and therefore that the GM, which occurs in the vadose zone in its area of outcrop, is present beneath the water table farther north. The relation of a layer of gypsum to the water table is important because the behavior of gypsum as a geological agent depends on the hydrology of its environment. It is worth emphasizing that, as noted above, except in acid water, gypsum solubility is greater than carbonate solubility (often by an order of magnitude) and that, unlike carbonate solubility, it is little affected by the $\mathrm{pH}$ changes produced by decaying vegetation in associated soils.

Within the vadose zone, i.e. primarily in the area over which the GM crops out, gypsum responds to water from rain merely by dissolving, thus contributing to local relief, and disappearing from outcrops. The chemical effect of vadose zone dissolution is the addition of sulfate and calcium ions to runoff and groundwater. The added sulfate can have important environmental effects, but, in carbonate terrains, addition of calcium is likely to be important only for secondary chemical reactions related to common ion precipitation. However, gypsum behavior below the water table can be particularly important if groundwater is flowing. If not initially saturated, water flowing through channels in bedded gypsum will obviously open those channels, enlarge voids, and provide positive feedback for further subsurface dissolution of gypsum, calcite, dolomite, and other minerals and for transport in suspension of silicates, especially argillite. These processes, working together, can produce subsurface erosion and collapse. They may also add sediment at the point of discharge.

\subsection{OUTGROP EXTENT AND THIGKNESS OF THE GYPSUM MEMBER}

Access to EIR geology improved significantly in 2009 when widening and partial levelling of the Mexican Highway 186 occurred. This road crosses most of the Yucatán Peninsula at approximately $18.5^{\circ} \mathrm{N}$ and essentially bisects the outcrop area of the GM, exposing important new outcrops of massive gypsum beds. The teeth of excavating equipment (used in the highway construction) have left distinctive impressions in these soft gypsum beds, making them easy to identify and follow for several kilometers. This suggests a possible novel application of the well-known website Google Earth "Street View" where prominent gypsum outcrops can readily be identified in highway traverses. For example, one of the most informative outcrops along the highway occurs at and near coordinates $18.530^{\circ} \mathrm{N}, 89.576^{\circ} \mathrm{W}$ (Figures 1 and 3). There, stacked beds (each individual bed about a meter thick) of coarsely crystalline, gently folded gypsum are outlined by thinner beds of clay. Displacing the bedded gypsum at this outcrop there are what appear to be two "intrusions" of a very poorly sorted siliciclastic rock consisting of an argillite matrix supporting much coarser rock fragments. In a second nearby outcrop (Figure 4), blocks of gypsum rock (more than a meter in 
maximum dimension) "float" in a similar siliciclastic intrusion, emphasizing the fluidity of the siliciclastic material. In a quarry that is on the opposite side of the hill from the exposure shown in Figure 3, there is an exposed wall of about $25 \mathrm{~m}$ of coarsely crystalline gypsum (Figure 5). In 2008, a slump on the west side of that wall was exposed to view (Figure 6). The highly deformed beds in that outcrop, outlined in red clay, are a further indication of mass movement probably lubricated by water. (This slump structure has subsequently been removed by quarrying.)

A definitive estimate of the thickness of the GM is not possible, because complete outcrops are lacking. We estimate a minimum thickness of 25-35 m based on the following: 1) an estimate of $25 \mathrm{~m}$ exposed in the quarry face in Figure 5; 2) a quarry of similar size in which excavation has proceeded in stages giving only a general impression of thickness; and 3) the $35 \mathrm{~m}$ thick subsurface occurrence of massive gypsum in drill core UNAM6 described by Lefticariu et al. (2006), which, as noted in section 4.2, we correlate with the GM of the Icaiche Formation.

\section{Regions arguably affected by surface or subsurface weathering of gypsum of the Gypsum Member}

\subsection{LIVING ON A GYPSIFEROUS SUBSTRATE: GONSTRAINTS ON HUMAN ACTIVITY FROM SULFATE-CONTAMINATED WATER}

The effect of gypsum on the groundwater of the EIR is profound. This is one of the major reasons why this region has remained almost unpopulated for about a thousand years after it was abandoned. It is quite remarkable that a large population could once have accommodated to local conditions by developing facilities for capturing and storing rainwater during the Maya Classic period. The Maya, living in the EIR, were able to develop these storage and distribution facilities for rainwater because of the presence of impermeable clay layers that do not exist in the better known coastal area of Campeche, Yucatán state, and Quintana Roo. The clays cover the floor of shallow karst depressions (bajos), which the Maya extended and

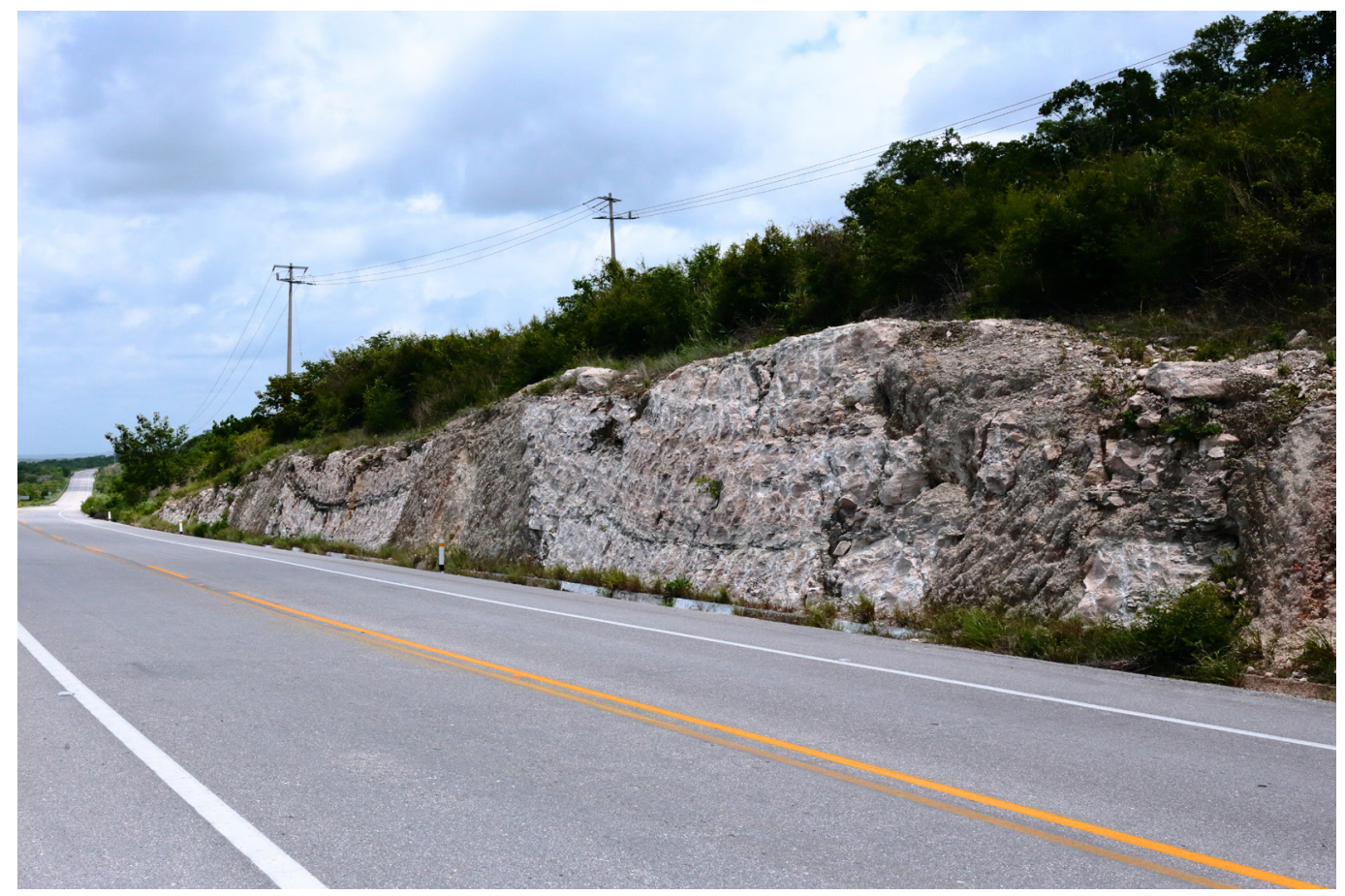

Figure 3 Roadcut in massively bedded gypsum layer of the Icaiche Formation along Highway 186. Note "intrusions" of poorly sorted argillite. At $18.530^{\circ} \mathrm{N}, 89.576^{\circ}$ W. Labeled "Prominent Gypsum Outcrop" in Figure 1. 
deepened (and also imitated) to form large reservoirs (Matheny et al., 1983; Gunn et al., 2002; Dunning et al., 2012).

Analyses of water from Lake Silvituk and Lake Zoh by Wagner (Wagner, 2009; Perry et al., 2011) are presented in Table 1 and show that shallow lakes (and by extension modified bajos of the Maya) can store remarkably ion-free water. Water from Lake Zoh (Table 1) is of special interest because it is within only a few hundred meters of a town well that pumps water with a sulfate concentration too high for human consumption. The EIR extends across the Mexico-Guatemala border. Near its southern margin (at El Palmar in Petén, Guatemala), water held in a lake (Cival) above a clay layer has similarly low sulfate, whereas underlying

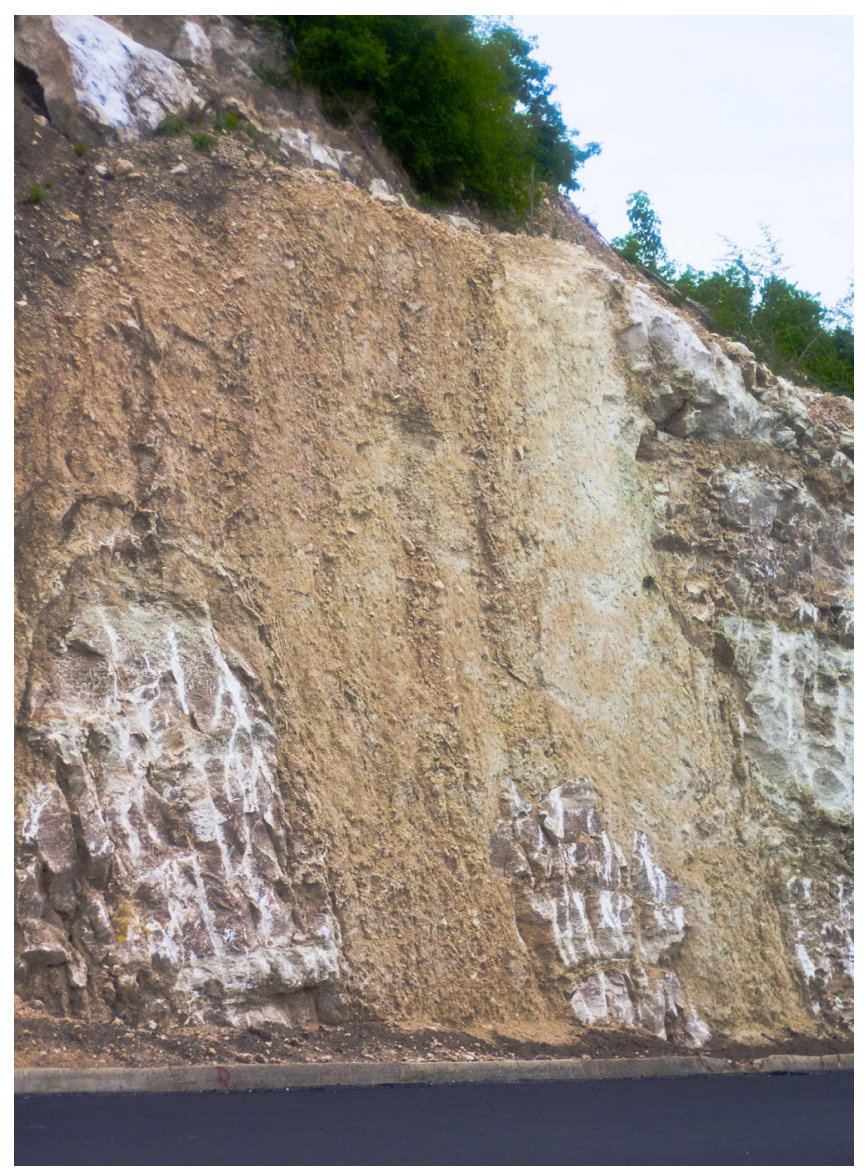

Figure 4 Blocks of massive GM caught up in poorly bedded argillite, part of the same outcrop as in Figure 3 and about $50 \mathrm{~m}$ east of that outcrop. Note distinctive tooth marks of the excavating equipment that identifies soft, ductile gypsum and can be used for a virtual field trip along Highway 186 in Google Earth "Street View." groundwater in an aquifer confined by the clay layer has high sulfate (Beach et al., 2015b).

Today, despite efforts by the Mexican federal government and by the government of Campeche to resettle the EIR, the area remains one of the least populated parts of Yucatán, mostly because of the lack of potable water. In a resettlement program, initiated by the Mexican government in the 1960s (Ericson et al., 1999), farmers from densely populated parts of Mexico were brought to this area. One resettlement community, La Guadalupe, consisting of 282 people (NavarroOlmedo, 2016), has a hand-dug town well in which the sulfate content is about 6 times US-EPA standards for human consumption (SDWA,1996) (Table 1). Near this well, there is a spring in which gypsum crops out in direct contact with spring water. Water from this spring is similar in chemistry to the town well (Table 1). Residents of La Guadalupe rely on drinking water furnished by CONAGUA, the National Water Commission of Mexico, and brought by tank trucks. CONAGUA also supplies water (obtained outside the region) to the municipality of Xpujil, the major population center of the region, through two pipelines: one (57 km long) brings water from Lake Alvarado, the other (100 km long) brings water from Constitución.

A drought in 2005 (Proceso, 2005) demonstrated that water supply is almost as tenuous today for the 28000 inhabitants of Calakmul County, as it was for the Maya of the Classic period (Dunning et al., 2016). In that year, rain-fed Lake Alvarado dried up causing real hardship in the region. CONAGUA responded by drilling a supply well in the southeast, just outside the area of contaminated water, and sending the water to Xpujil through the Alvarado pipeline.

\subsection{THE POGKMARKED TERRAIN: A DISTANT KARST AREA PROBABLY AFFECTED BY BURIED GYPSUM MEMBER ROCKS}

A second way in which the Icaiche Formation affects geomorphology and hydrogeology of the northern Yucatán Peninsula is not obvious because it occurs far from the nearest Icaiche outcrop. It is 


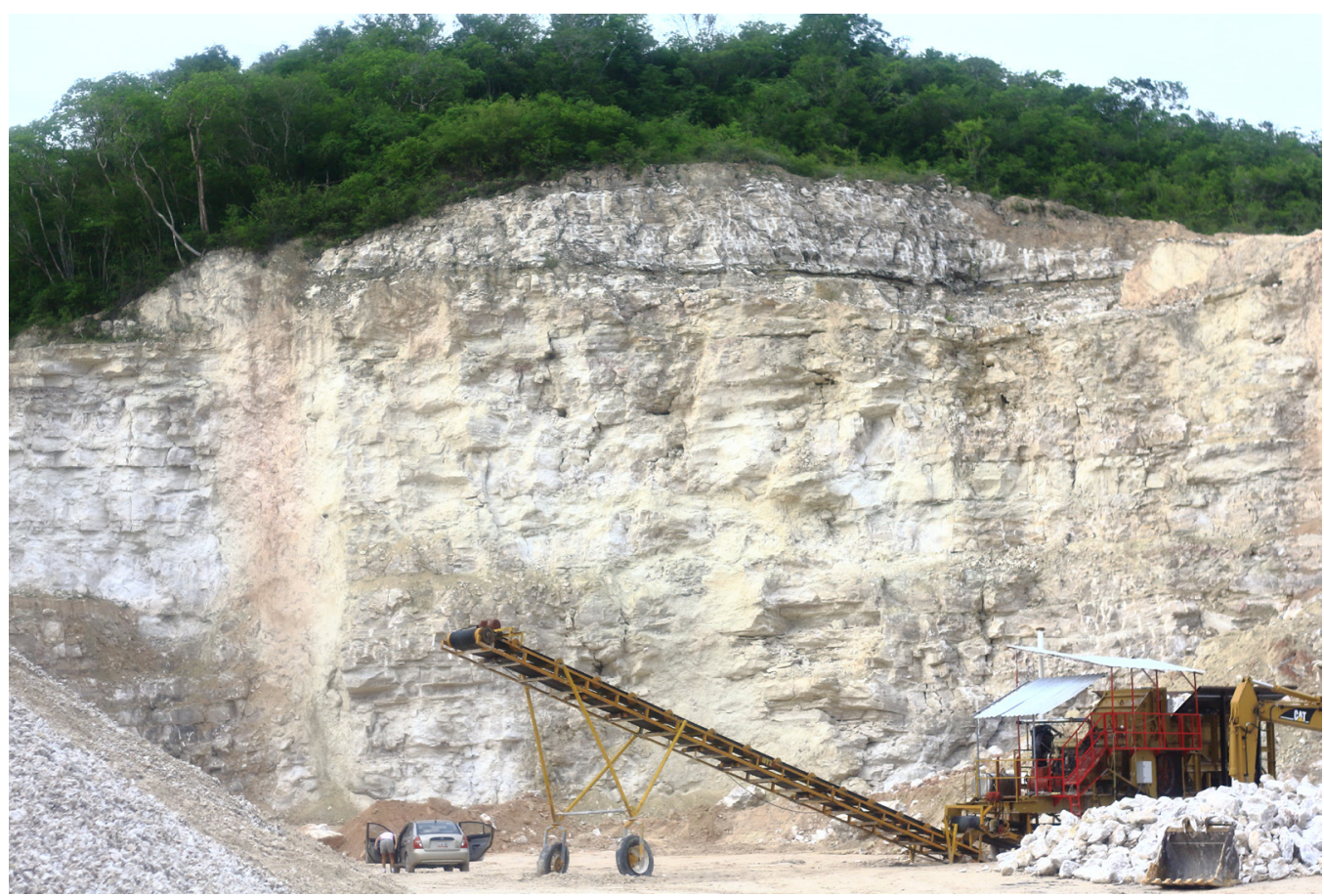

Figure 5 A wall of massively bedded gypsum of the GM of the Icaiche Formation exposed in a quarry $500 \mathrm{~m}$ west of Figure 3 . Estimated thickness: $25 \mathrm{~m}$. Photograph taken in 2008.

probable that the GM of the Icaiche Formation is responsible for the development of the distinctive form of karst, characterized by a dense population of deep cenotes and aguadas, that constitute the Pockmarked Terrain of north central Yucatán state (Perry et al., 2002), about $160 \mathrm{~km}$ north of the nearest Icaiche outcrop.

Please note that the regional nomenclature for karst depressions is somewhat variable and can be ambiguous. Here, we use the word cenote (from the Maya tzonot) to refer to a specific type of water-filled sinkhole common in northern Yucatán (Schmitter-Soto et al., 2002). We specifically invoke the implied but generally unstated condition that all these northern cenotes have a subsurface hydraulic connection with the ocean and with each other, tapping into a regional water table controlled by msl. The distinction is important in discussion of Cenotes Ucil and Xcolak in this section and particularly in section 6, where we discuss Cenotes Ocom and Nohbec. The latter cenotes differ distinctly from neighboring water bodies that are perched lakes not in equilibrium with the ocean. We use aguada to specify a sinkhole that is partially filled with sediment that blocks its direct connection to the regional water table. In other discussions of southern parts of the EIR, this usage may differ.

The presence of the GM gypsum more than 100 $m$ beneath the surface in the Pockmarked Terrain was inferred by Gmitro (1986), Perry et al. (2002) and Socki et al. (2002). This assumption was based on high sulfate and strontium ion content of the water at the base of the water column 100 m-deep in Cenote Ucil $\left(20.990^{\circ} \mathrm{N}, 88.600^{\circ} \mathrm{W}\right)$ and 120 $\mathrm{m}$ in Cenote Xcolac $\left(20.909^{\circ} \mathrm{N}, 88.857^{\circ} \mathrm{W}\right)$, also spelled Xcolak and Xkolac. It is worth mentioning that strontium, a minor element present in gypsum of marine origin, is a better groundwater tracer element for gypsum $\left(\mathrm{CaSO}_{4} \cdot 2\left(\mathrm{H}_{2} \mathrm{O}\right)\right)$ than either calcium, which is ubiquitous in carbonate-saturated groundwater, or sulfate, which is readily reduced to sulfide by organic matter in sinkhole water. Correlation of the subsurface gypsum of the Pockmarked Terrain with the GM is also supported by the presence of a $35 \mathrm{~m}$ layer of 


\begin{tabular}{|c|c|c|c|c|}
\hline Sample & $\begin{array}{l}\text { Latitude }\left({ }^{0} \mathbf{N}\right) / \\
\text { Longitude }\left({ }^{\circ} \mathbf{W}\right)\end{array}$ & $\begin{array}{l}\text { Chloride } \\
(\mathrm{mEq} / \mathrm{L})\end{array}$ & $\begin{array}{c}\text { Sulfate } \\
(\mathrm{mEq} / \mathrm{L})\end{array}$ & $100 \mathrm{xSO}_{4} / \mathrm{Cl}$ \\
\hline $\begin{array}{c}\text { La Guadalupe } \\
\text { Well }\end{array}$ & $18.33 / 89.48$ & 16.29 & 36.46 & 224 \\
\hline $\begin{array}{l}\text { La Guadalupe } \\
\text { Spring }\end{array}$ & $18.33 / 89.48$ & 9.93 & 32.41 & 326 \\
\hline Zoh Well & 18.59 / 89.42 & 7.9 & 31.49 & 400 \\
\hline Zoh Lake & 18.59 / 89.42 & 0.23 & 0.03 & 13 \\
\hline Lake Silvituk & $18.63 / 90.31$ & 0.2 & 0.04 & 20 \\
\hline $\begin{array}{c}\text { Nuevo Israel } \\
\text { Well }\end{array}$ & $19.00 / 88.57$ & 6.1 & 25.1 & 414 \\
\hline $\begin{array}{c}\text { Lake } \\
\text { Chichancanab }\end{array}$ & 19.84 / 88.76 & 7.4 & 52.9 & 712 \\
\hline
\end{tabular}

recrystallized massive Paleocene/Eocene gypsum overlying Paleocene collapse breccia in rock core from UNAM6, an observation well drilled near Peto, $50 \mathrm{~km}$ north of the nearest Icaiche Formation outcrop (Lefticariu et al., 2006).

A mechanism for producing the deep sinkholes of the Pockmarked Terrain is provided by the discovery of a set of ring fractures along the eastern edge of the Chicxulub Impact by offshore seismic measurements of Gulick et al. (2008). As set forth by Perry et al. (2009), these deep fractures may provide a pathway for groundwater movement, especially during times of lower sea-stand. Here is how Perry et al. (2009) explained why karst development of gypsum would be more likely in a deep, saline intrusion than development of limestone karst in that environment. The shallow pre-Paleogene basement faults reported by Gulick et al. (2008):

...may have resulted in exceptional permeability development, opening this zone to extensive groundwater penetration. The enhanced permeability, of itself, may have been sufficient to produce subsurface dissolution of both carbonates and evaporites. However, in con- trast to carbonate dissolution, solubility of gypsum, anhydrite, and celestite is not directly $\mathrm{pH}$ dependent and thus is perhaps more likely to take place within the saline intrusion, well below the water table, if deep groundwater circulation occurs. In that case, expansion accompanying hydration of anhydrite may have preceded and accelerated dissolution of gypsum associated with impact ejecta [or more probably GM] to produce the subsurface erosion that contributed to collapse features in the area.

In summary, given the extensive surface exposure of the GM and our ability to trace it northward in the subsurface, we consider the dissolution of buried Icaiche Formation gypsum the most likely mechanism by which the unique Pockmark Terrain developed $160 \mathrm{~km}$ from the nearest Icaiche outcrop.

\subsection{POLJES, PROBABLY FORMED BY SUBSURFACE DISSOLUTION OF GYPSUM}

A third geomorphic/hydrogeology result of the GM dissolution may have been the formation of the poljes of Southern Campeche and Quintana 
Roo. These are closed, often interconnected basins that are $40 \mathrm{~km}$ or more in their longest dimension (Figure 1) (SGM, 2017). They are floored by residual clays derived from the weathering of aeolian inputs and insoluble residues of limestone weathering. They also have complicated internal drainage patterns that do not seem to "go anywhere," at least on the surface. They offer agricultural potential in the form of water storage and thick (although nutrient-poor) soil. But this potential has not been exploited everywhere because it is often counterbalanced by the seasonal tendency toward flooding during rainy periods and desiccation during drought (Gunn et al., 2002; Dunning et al., 2012). However, the development of aprons of cumulic, base-rich soils derived from soil erosion on adjacent uplands on the footslopes and toeslopes bordering many low lands (bajos) created zones with high productive potential that were exploited with intensive cultivation (Dunning et al., 2002, 2006, 2015). Swampy areas and thick vegetation can impede access, a fact made clear by the name of one of the most extensive poljes: "Sal Si Puedes (get out if you can)" (Figure 1).

Except for what evaporates, rainwater falling on these poljes must leave through some sort of drain, and both the volume of accumulated residual sediment on the valley floor and the mass lost to form the depressions require that large amounts of material were transported in solution and suspension out of each basin. A question that arises is what is their plumbing system? We suggest it is not a coincidence that the large poljes of the region are located on or adjacent to the outcrop area of the Icaiche Formation with its near-horizontal beds of gypsum. We submit that the poljes were formed by underground dissolution of gypsum, which opened subterranean passageways carrying water, dissolved limestone and suspended siliciclastics out of the EIR region, followed by collapse of rocks above creating something analogous to enormous sink holes. The poljes of Turkey and elsewhere in Eastern Europe and the Middle East are commonly associated with evaporites (Doğan, and Yesilyurt,
2004). In support of this mechanism, Laguna $\mathrm{Om}\left(18.49^{\circ} \mathrm{N}, 89.08^{\circ} \mathrm{W}\right)$ drained rapidly and unexpectedly and then quickly refilled in August, 2018 (Leal-Bautista, personal observation). Lake Om lies about $2 \mathrm{~km}$ east of a north-south line of gypsum quarries and is part of a chain of shallow lakes about $10 \mathrm{~km}$ long, trending NNE-SSW, more or less paralleling faults in southeastern Quintana Roo. It is at the southwestern junction of intersecting Poljes Nuevo Becak and Morocoy. LealBautista is investigating the possibility that this lake drainage is part of a continuing subsurface drainage process by which the joint Poljes Nuevo Becak-Morocoy is becoming extended.

\subsubsection{POSSIBLE FATE OF SILICICLASTIC RESIDUES OF POLJE FORMATION}

We assert that the "intrusions" of unsorted, dominantly siliciclastic sedimentary material into bedded evaporite of the GM (Figures 3 and 4) must have been emplaced as mobile, water-rich fluids. Probable source materials include: 1) argillite interbedded with gypsum in the GM (red layers in Figure 6 and the dark layer in Figure 3); and 2) argillite derived from devitrified glass of the Albion Formation (Pope et al., 2005). This suggests an answer to an apparently unrelated question: What is the source of impermeable clay in post-Eocene sedimentary marine rocks deposited to the east of the EIR? Section 6 describes characteristics of these younger carbonate rocks indicative of relatively high argillite content. For example, the Miocene Estero Franco and Bacalar Formations and, in particular what may be a local, low-permeability facies of the Carrillo Puerto Formation all support perched water tables. We suggest that the material in the intrusions shown in Figures 3 and 4 may be representative of siliciclastic insoluble residues removed during the process of subsurface erosion that formed poljes and that these sediments were subsequently incorporated into carbonate sediments being deposited offshore. 


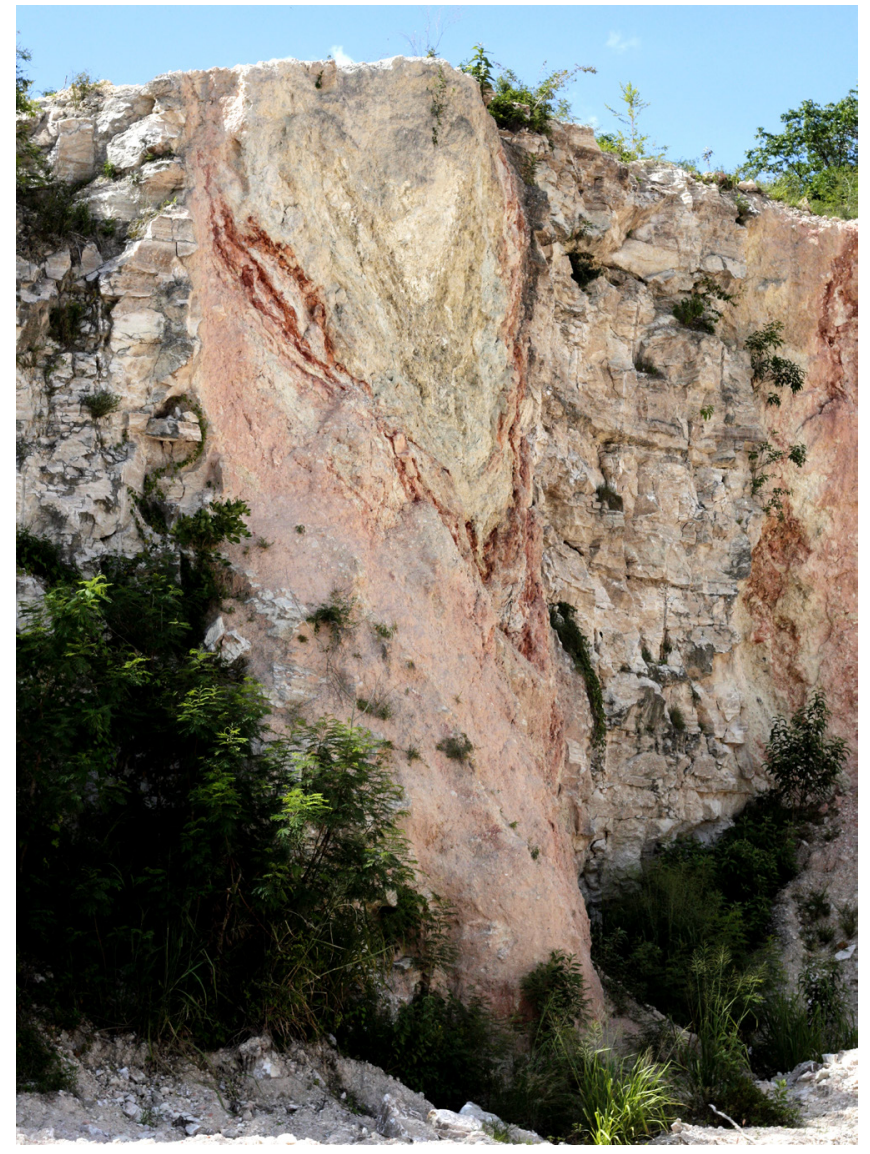

Figure 6 A slump structure in the same quarry as shown in Figure 5 . The feature had been excavated, hence removed, before the photograph of Figure 5 was taken.

\section{The Ticul Fault}

\subsection{THE TICUL FAULT, A USEFUL BUT INEXACT MARKER OF HYDROGEOLOGICAL REGIONS}

In 1970 Back and Hanshaw proposed that the aquifer system of the northernmost Yucatán Peninsula consists of a lens of fresh water floating on a denser saline intrusion within a permeable carbonate aquifer. That model was developed by Hanshaw and Back, (1980) and Back et al. (1986) and has been tweaked many times by numerous investigators in the ensuing 47 years; but it remains generally valid.

Perhaps reflexively, it has become easy to envision the hydrogeology of the entire Mexican part of the Yucatán Peninsula as fitting a variation of the Hanshaw and Back (1980) model, but that is wrong. There is no evidence for a saline intrusion beneath outcrops of the Iaiche Formation (Perry et al., 2011). However, the precise boundary between the permeable rocks in the north (that support a saline intrusion) and the rocks in the south (that do not support it) is difficult to establish. Dunning et al. (2012) have used the Ticul Fault as the northern boundary for the EIR, and that is a valid divider for archeological purposes (Beach, 2017). The ruins of a group of Maya cities that is noted for distinctive Puuc style architecture, occupies the northwest corner of the EIR. These impressive cities, including Oxkintoc right on the fault, Uxmal (14 km south of the fault), and Sayil (21 km south of the fault) flourished between 700 and $950 \mathrm{CE}$. Their residents did not have access to groundwater, and in that sense these cities were like the southern cities of the EIR and were utterly dependent on capturing and storing rainwater. However, the Puuc cities were built on the porous, permeable rocks of the Chichen Itza Formation that does support a saline intrusion and has an aquifer, which, although it was too deep to be accessible by pre-Colonial technology, now supplies groundwater to deep wells at Uxmal and Sayil (Perry et al., 2002). For reference, the water table in nearby Santa Elena $(10 \mathrm{~km}$ south of the Ticul Fault) lies at a depth of $92 \mathrm{~m}$ (Perry et al., 2002).

\subsection{THE TIGUL FAULT AS A GONDUIT FOR GROUNDWATER FLOW}

The up-thrust southern block of the normal Ticul Fault of Eocene age (McClain, 1997) is a conspicuous, well-defined landmark in south central Yucatán state, rising directly south of its eponym, the town of Ticul $\left(20.40^{\circ} \mathrm{N}, 89.535^{\circ}\right.$ $\mathrm{W})$, to a height of almost $100 \mathrm{~m}$ above the downdropped, flat lowland plain of northern Yucatán. This scarp, which forms the northern boundary of the southern block and of the EIR, continues to dominate the landscape as far as Tzucacab $\left(20.206^{\circ} \mathrm{N}, 89.290^{\circ} \mathrm{W}\right), 60 \mathrm{~km}$ southeast of Ticul 
(Figure 1). The fault is an important conduit for groundwater movement, carrying water from the vicinity of Lake Chichancanab $\left(19.840^{\circ} \mathrm{N}\right.$, $88.760^{\circ} \mathrm{W}$ ) westward to the fault system that surrounds the Chicxulub impact and thence into the Celestun Estuary and the Gulf of Mexico (Perry et al., 2002; Perez-Ceballos et al., 2012). The Ticul Fault is important to an understanding of the geomorphic importance of the GM because, as we show in the next section, it is the major conduit by which sulfate (a proxy for dissolved gypsum) has been transported out of the region around Lake Chichancanab.

\subsection{DISSOLUTION OF GYPSUM BELOW THE WATER TABLE: A SIMPLE MODEL TO EXPLAIN ONGOING EVOLUTION OF A GOMPLEX GEOMORPHIC REGION}

In the $16 \mathrm{~km}$, between Tzucacab $\left(20.070^{\circ} \mathrm{N}\right.$, $\left.89.050^{\circ} \mathrm{W}\right)$ and Catmis $\left(19.960^{\circ} \mathrm{N}, 88.950^{\circ} \mathrm{W}\right)$ (Figure 1), the exact position of the Ticul Fault becomes difficult to discern in the field. Consequently, the fault trace is marked in the map of SGM (2017) (and correspondingly on Figure 1) as a dashed line. We think it is significant that, within that distance, there is also a notable change in groundwater chemistry. Groundwater from Tzucacab has a $\mathrm{SO}_{4} / \mathrm{Cl}$ equivalent ratio of 1.03, whereas the ratio at Catmis is 1.8, with corresponding $\mathrm{SO}_{4}$ equivalent concentrations of 12.1 and $19.7 \mathrm{mEq} / \mathrm{L}$, respectively (Perry et al., 2002). Both, these sulfate concentrations and $\mathrm{SO}_{4} / \mathrm{Cl}$ ratios, are high and strongly suggest groundwater contact with a sulfate source (gypsum). Southeast of Catmis, the map of SGM (2017) continues to show a dashed trace (denoting uncertainty) for the Ticul Fault for $120 \mathrm{~km}$ to Cenote Nohbec $\left(19.100^{\circ}\right.$ $\mathrm{N}, 88.210^{\circ} \mathrm{W}$ ) and beyond. This section of the fault passes by the southern end of Lake Chichancanab, whose water is approximately saturated with respect to gypsum (Perry et al. 2002; Hodell et al., 2005).

Perry et al. (2002) used water chemistry and lake elevation as a basis for postulating that groundwater from the vicinity of Lake Chichancanab moves west through the Ticul Fault into the Gulf of Mexico. Combining information on the map of SGM (2017) with these previously reported geochemical data, we can now make stronger statements: 1) It is highly probable that GM is present in the shallow subsurface of this area as it is in much of the northern Peninsula, and also that 2) groundwater moving through the Ticul Fault is actively dissolving gypsum of this unit and removing it - in effect performing a natural analog of "solution mining". Evidence for the aforementioned can be best evaluated by referring to regional characteristics summarized in Table 2. Removal of gypsum by dissolution can explain the common occurrence of calcareous breccia noted on the map of SGM (2017) in quarries flanking the Ticul Fault trace (much more abundant on the down-dropped northern side).

Calcareous breccia is also abundant in outcrops within the town of José María Morelos (JMM) and in road-cuts near the town. We suggest that these are collapsed breccias above caverns produced by gypsum dissolution. Water chemistry provides additional evidence of heterogeneous distribution of gypsum in the subsurface in the vicinity of JMM where residents queried by Perry (unpublished personal observation, 2013) reported wide local differences in the quality of well water. This variability is documented (Perry et al., 2002) in a pair of wells near the fault trace and about a kilometer apart at Chunhuhub (Figure 1). The $\mathrm{SO}_{4}$ / $\mathrm{Cl}$ ratio measured for water in the Chunhuhub town well was 1.74 , whereas the ratio for water in a nearby well at an agricultural station was 9.01. The respective sulfate concentrations were 7.29 and $18.93 \mathrm{mEq} / \mathrm{L}$. This high local variability in the concentration of sulfate in groundwater suggests that removal of gypsum by dissolution is an active, ongoing process.

It is worth noting that sulfate is a strong laxative, and high sulfate values are deleterious to a number of crops. The lower value exceeds Mexican (NOM- 127 SSA-1994) and US standards for drinking water (SDWA, 1996), and the higher value is one of the highest measured in waters of Yucatán. 
As noted above, the trace of the Ticul Fault is projected to run through Cenote Nohbec, which has a water elevation of 1-2 $\mathrm{m}$ above msl according to Google Earth (accessed 28/02/2018). That confirms Lake Chichancanab (elevation $4 \mathrm{~m}$ ) as a groundwater divide and suggests why the Ticul Fault is a strong transport agent removing gypsum from the region. In fact, the 50 m.y. Eocene fault is considerably older than the 5 m.y. Pliocene Carrillo Puerto Formation that overlies the fault divide in this region, suggesting that the diffuse path of the fault here is visible precisely because it is projected up to the surface as a result of subsurface erosion of underlying gypsum.

Table 2. Features related to the transitional hydrology of the eastern "Ticul Fault Zone".

\begin{tabular}{|l|l|l|l}
\hline Feature & Location or Entity & Possible Significance & Notes \\
\hline
\end{tabular}

Noted on the map of SGM (2017) for quarries in a band east and west of Ticul Fault Suggests collapse related to "Calcareous Breccia"

Surface water level elevation within about 4 above msl.

Water saturated or nearly saturated with gypsum. Gypsum precipitating on shore.

9000-year record of climate and of lake elevation.

Nohbec: a cenote in the form $19.142^{\circ} \mathrm{N}, 88.168^{\circ} \mathrm{W}$. of a meander, sitting on the Carrillo Puerto Fm.

Chain of cenotes, including Ocom, occupying the channel of a "fossil" meandering stream.

Channels for overland flow into Cenotes Ocom and Nohbec.
Lake Chichancanab $19.840^{\circ} \mathrm{N}, 88.760^{\circ} \mathrm{W}$ One arm of Cenote Nohbec is on the Ticul Fault trace. $19.470^{\circ} \mathrm{N}, 88.100^{\circ} \mathrm{W}$

Lakes Esmeralda and Chichancanab, Cenotes Ocom and Nohbec.

Lake Chichancanab $19.840^{\circ} \mathrm{N}, 88.760^{\circ} \mathrm{W}$

Can be observed in Google Earth
Indicates hydraulic contact with an aquifer whose level is controlled by the ocean (msl).

Water in direct contact with gypsum.

Indicates slow (months, years) but regular (longer scale) response to sea level change.

Suggests that a relatively impermeable facies of the Carrillo Puerto Fm once supported perched stream flow above msl.

Ocom is within a meter of msl.

Show clearly on NASA Image PIA03379. Indicates surface movement over low permeability rocks.
Also notable in street and road cuts in and around the town José María Morelos.

Measured on Google Earth. Lake Esmeralda measurement reported in Perry et al . (2002).

Reported by Perry et al. (2002).

Hodell et al. (2005)

One of several "fossil" stream channels evident on the map of SGM (2017) and on Google Earth

Best example of stream captured by base level (msl) aquifer.

Illustrate permeability (facies) change in the south of the Carillo Puerto Fm. 


\section{Further suggestions about the complex landforms and hydrology of eastern Yucatán}

Several regional geomorphic features (Table 2), which probably developed during a period of pre-modern precipitation, suggest that post-Eocene rocks bordering the EIR on the east are sufficiently impermeable as to constitute aquitards. These include meander-like features, resembling "fossil" stream channels that are filled by permanent or ephemeral bodies of open water, several meters or more above msl. Most of these do not appear to be influenced by karst processes. However, one apparent fossil stream channel, that is particularly helpful in interpreting an evolving landscape, is occupied by Cenote Ocom (Table 2), which is one of eight cenotes that have water elevations of approximately 1-2 $\mathrm{m}$ above msl. These cenotes all occupy a sinuous basin, labeled "Lake Ocom" in Figure $1\left(19.47^{\circ} \mathrm{N}, 88.07^{\circ} \mathrm{W}\right)$, that resembles a stream meander as can be seen clearly in Google Earth. We interpret this assemblage as recording the history of a perched stream that has been let down by erosion to modern base level.

A reconnaissance inspection of local quarries (Leal-Bautista and Cejudo, 2017) confirmed that layers of expanding clay are common in local rocks, including rocks of the Carrillo Puerto Formation, which is more permeable in northwestern Yucatán than here. One possibility, proposed in section 4.3.1, is that these eastern, post-Eocene rocks contain considerable argillaceous material eroded from the EIR and transported eastward as the younger rocks were deposited. Provenance studies could usefully test this suggestion. The significance of these observations is that the presence of aquitards above the GM may have protected layers of gypsum in this region until subsurface channels developed relatively recently along the Ticul Fault as a result of dissolution and erosion from below. This mass transport, followed by the erratic, incomplete subsidence that is presently observed in the region, may have been stimulated by Pleistocene and perhaps earlier sea level variations.

\section{Ad hoc explanations for selective dissolution of gypsum in the eastern down-dropped Fault Block}

Where it is well exposed in the northwest, the Ticul Fault is normal and down-dropped to the north. That may pose a problem for the subsidence and subsurface erosion model we propose here. Specifically, why is erosion occurring in the down-dropped block near the fault, whereas, except in the immediate vicinity of Lake Chichancanab, calcareous breccia is not shown on the upthrust fault block on the map of SGM (2017). Our provisional answer is that the solution mining through the Ticul Fault, that we postulate, is much more effective below the water table than above, particularly near this coastal area that has experienced repeated large changes in sea level. It may also be worth mentioning that the Yucatán Peninsula was once a tectonically active region (Rosencrantz, 1990) and that the gypsum-anhydrite transition occurs at low temperature (Jowett et al., 1993). Dehydration of gypsum and rehydration of anhydrite would preferentially occur in the more deeply buried down-dropped fault block and would involve volume changes of almost $40 \%$, probably sufficient to cause brecciation and permeability increase.

\section{Effect of gypsum karst on regional settlement}

There is little evidence that, before the Spanish invasion of 1521, there was extensive Maya occupation of sites in the area that lies east and south of Lake Chichancanab and extending to Lake Bacalar on the south (Witschey and Brown, 2010); and, after early bloody skirmishes with Mayas (Chamberlain, 1948), the area was largely ignored by Spanish colonials. Beginning in the 1840s, the region was occupied by indios rebeldes: Mayas who found here a safe refuge, in a wild place of dense vegetation and few roads, after they were defeated during a massive uprising. Until the mid $-20^{\text {th }}$ cen- 
tury the area was occupied largely by rebellious Mayas, itinerant chicleros (harvesters of chicle from Manilkara zapota trees) and loggers. Today the largest towns are José María Morelos, not established as capital of a municipio until 1974, and the former rebel Maya town of Chan Santa Cruz, renamed Felipe Carrillo Puerto in 1930. Thus, this region remained largely undeveloped until it was overtaken by a wave of tourism that began in the mid-1970s. We suggest that this late and slow development may have been, in part, a function of the distinctive karst characteristics of the region. Irregular topography, variable soil development, and poor water quality (resulting from gypsum of the GM exposed to groundwater within a dynamic aquifer) may have combined to make the region relatively unattractive for permanent settlement.

\section{Conclusions}

We submit that the characteristics of the relatively little-studied Icaiche Formation and especially its GM have strongly influenced the hydrogeology, topography, and habitability of the Mexican portion of the Yucatán Peninsula. Rapid population growth in northern Quintana Roo will undoubtedly bring pressure for development of the EIR and of southern Quintana Roo. Potable water is a valuable resource likely to become increasingly scarce. The fact that many of our conclusions about the hydrogeology of the region are tentative emphasizes the need for a detailed geological study of rocks, sediments, and waters of the EIR and of the effects of the GM on surrounding areas.

\section{Acknowledgements}

This is Part I of a two-part study of the hydrogeology and aqueous geochemistry of southeast Quintana Roo. Part II will focus on a proposed deep aquifer in the south-easternmost part of the state. The broad scope of this paper, addressing topics from geochemistry to archeology, has led us to seek help from a number of researchers who have graciously responded. It is a pleasure to acknowledge institutional help from the National Water Commission of Mexico (CONAGUA) and especially from M. Eng. José Luis Acosta Rodríguez, Director Técnico from CONAGUA in Yucatán, and Eng. Iván Gamboa Rosas Secretario Técnico from CONAGUA in Quintana Roo. We are grateful to Dr. Eduardo Cejudo (Centro de Investigación Científica de Yucatán) for his help in the field. The following researchers, listed alphabetically, read parts or all of the manuscript (through various iterations) and provided valuable criticism. We have learned from each of them and gratefully acknowledge their help: Sheryl Luzzadder-Beach, Timothy Beach, David King, and Mihai Lefticariu. We also thank an anonymous reviewer for constructive criticisms that we have addressed as far as possible due to the limited data availability for the region. This study received support from the Centro de Investigación Científica de Yucatán. We take responsiblity for any errors in this manuscript.

\section{References}

Back, W., Hanshaw, B.B., 1970, Comparison of chemical hydrogeology of the carbonate peninsulas of Florida and Yucatan: Journal of Hydrology, 10, 330-368. https://doi. org/10.1016/0022-1694(70)90222-2

Back, W., Hanshaw B.B., Herman, J.S., Van Driel, J.N., 1986, Differential dissolution of a Pleistocene reef in the ground-water mixing zone of coastal Yucatan, Mexico: Geology, 14(2), 137-140. https://doi. org/10.1130/0091-7613(1986)14<137:ddoa pr>2.0.co;2

Bautista, F., Palacio-Aponte, G., Quintana, P., Zinck, J.A., 2011, Spatial Distribution and Development of Soils in Tropical Karst Areas from the Peninsula of Yucatan, Mexico: Geomorphology, 135 (3-4), 308-321.https:// doi.org/10.1016/j.geomorph.2011.02.014 
Beach, T.P., 2017, Morals to the Story of the "Mayacene" from Geoarchaeology and Paleoecology, in Sanz, N. (ed.), Exploring Frameworks for Tropical Forest Conservation: managing production and consumption for sustainability: Paris, France, UNESCO, 110-139.

Beach, T.P., Luzzadder-Beach, S., Cook, D., Dunning, N., Kennett, D.J., Krause, S., Terry, R., Trein, D., Valdez, F., 2015a, Ancient Maya impacts on the Earth's surface: An Early Anthropocene analog?: Quaternary Science Reviews, 124, 1-30. https://doi. org/10.1016/j.quascirev.2015.05.028

Beach, T.P., Luzzadder-Beach, S., Flood, J., Houston, S., Garrison, T., Roman, E., Bozarth, S., Doyle, J., 2015b, A Neighborly View: Water and Environmental History of the El Zotz Region, in Lentz, D., Dunning, N., Scarborough, V. (eds.), Tikal: Paleoecology of an Ancient Maya City: New York, USA, Cambridge University Press, 258-279.

Butterlin, J., Bonet, F., 1960, Información básica para la interpretación geohidrológica de la Península de Yucatán: México D.F., México, Reporte de la Secretaría de Recursos Hidráulicos.

Cabadas-Baez, H.V., Solliero-Rebolledo, E., Sedov, S., Pi-Puig, T., Alcalá, J.R., 2010, The Complex Genesis of Red Soils in Península de Yucatán Mexico: Mineralogical, Micromorphological, and Geochemical Proxies: Eurasian Soil Science, 43, 1439-1457. https://doi.org/10.1134/ s1064229310130041

Castellanos, J.E., Foias, A.E., 2017, The Earliest Maya Farmers of Peten: New Evidence from Buenavista-Nuevo San José, Central Peten Lakes Region, Guatemala: Hindawi Journal of Anthropology, Article ID 8109137, 45. https://doi.org/10.1155/2017/8109137

Chamberlain, R.S., 1948, The conquest and colonization of Yucatan: Washington, D. C., USA, The Carnegie Institution of Washington.
Doğan, U., Yesilyurt, S., 2004, Gypsum karst south of Imranli, Sivas, Turkey: Cave and Karst Science, 31, 7-14.

Domínguez, M. del R., Folan, W.J., 1996, Calakmul, México: Aguadas, bajos, precipitación y asentamiento en el Petén Campechano, in Laporte, J.P., Escobedo, H. (eds), IX Simposio de Investigaciones Arqueológicas en Guatemala, Nacional de Arqueología y Etnología: Guatemala, Guatemala, Ministerio de Cultura y Deportes, 147-173.

Dunning, N.P., Luzzadder-Beach, S., Beach, T.P., Jones, J.G., Scarborough, V.L., Culbert, T.P., 2002, Arising from the Bajos: The Evolution of a Neotropical Landscape and the Rise of Maya Civilization: Annals of the Association of American Geographers, 92, 267-282. https://doi.org/10.1111/1467-8306.00290

Dunning, N.P., Beach, T.P., Luzzadder-Beach, S., 2006, Environmental Variability Among Bajos in the Southern Maya Lowlands and its Implications for Ancient Maya Civilization and Archaeology, in Lucero, L., Fash, B. (eds.), Precolumbian Water Management: ideology, ritual, and power: Tucson, USA, University of Arizona Press, 81-99.

Dunning, N.P., Beach, T.P., Luzzadder-Beach, S., 2012, Kax and kol: Collapse and resilience in lowland Maya civilization: Proceedings of National Academy of Sciences, 109, 3652-3657. https://doi.org/10.1073/ pnas. 1114838109

Dunning, N.P., Griffin, R.E., Jones, J.G., Terry, R.E., Larsen, Z., Carr, C., 2015, Life on the Edge: Tikal, in a Bajo Landscape, in Lentz, D.L., Dunning, N.P., Scarborough, V.L. (eds.), Tikal: Paleoecology of an Ancient Maya City: New York, USA, Cambridge University Press, 95-123.

Dunning N.P., Brewer J., Beach T., LuzzadderBeach S., and Scarborough V., 2016, Ancient Water Collection and Storage in the Elevated Interior Region of the Maya Lowlands, in The 81st Annual Meeting of the Society for American Archaeology, Orlando, Florida. 
Ericson, J.A., Freudenberger, M.S., Boege, E., 1999, Population Dynamics: Migration, and the Future of the Calakmul Biosphere Reserve: Washington DC, USA, Program on Population and Sustainable Development (PSD), American Association for the Advancement of Science (AAAS).

Flores, G., 1952, Summary report of the preliminary geological studies of the area $\mathrm{N}$ of $17^{\circ} \mathrm{N}$ latitude, British Honduras: Bahamas, Bahamas Exploration Company, Freeport.

Gmitro, D.A., 1986, The interaction of water with carbonate rocks in Yucatan, Mexico: DeKalb, IL., USA., Northern Illinois University, Master Thesis.

Google, Map data: Google, DigitalGlobe, consulted February 2017.

Google, Map data: Google, DigitalGlobe, consulted October 2018.

Gulick, S.P.S., Barton, P.J., Christeson, G.L., Morgan, J.V., McDonald, M., MendozaCervantes, K., Pearson, Z.F., Surendra, A., Urrutia-Fucugauchi, J., Vermeesch, P.M., Warner, M.R., 2008, Importance of preimpact crustal structure for the asymmetry of the Chicxulub impact crater: Nature Geoscience, 1 (2), 131-135. https://doi. org/10.1038/ngeo103

Gunn, J.D., Foss, J.E., Folan, W.J., Domínguez, M. del R., Faust, B.B., 2002, Bajo sediments and the hydraulic system of Calakmul, Campeche, Mexico: Ancient Mesoamerica, 13 (2), 297-315. https://doi.org/10.1017/ s0956536102132184

Hanshaw, B.B., Back, W., 1980, Chemical masswasting of the northern Yucatan Peninsula by groundwater dissolution: Geology, 8(5), 222-224. https://doi.org/10.1130/0091$7613(1980) 8<222:$ c motny $>2$. 0 . co;2

Hodell, D.A., Brenner, M., Curtis, J.H., 2005, Terminal Classic drought in the northern Maya lowlands inferred from multiple sediment cores in Lake Chichancanab, Mexico: Quaternary Science Reviews, 24, 1413-1427. https://doi.org/10.1016/j. quascirev.2004.10.013
Jowett E.C, Cathles III, L.M. and Davis ,B.W., 1993, Predicting depths of gypsum dehydration in evaporitic sedimentary basin: AAPG Bulletin, 77 (3), 402-413

Leal-Bautista, R., 2018, colapso Laguna Om o Chakan Bakan, Municipio de Othón P. Blanco: Quintana Roo, México, Reporte presentado a PROFEPA Agosto 18.

Leal-Bautista, R., Gejudo, E.E., 2017, Reporte de campaña-zona: Felipe Carrillo-San Pedro Santos-Chunhuhub, Quintana Roo, México, Centro de Investigación Científica de Yucatán Unidad de Ciencias del Agua, Reporte trabajo de campo febrero-marzo.

Lefticariu, M., Perry, E.C., Ward, W.C., Lefticariu, L., 2006, Post-Chicxulub depositional and diagenetic history of the northwestern Yucatan Peninsula, Mexico: Sedimentary Geology, 183, 51-70. https:// doi.org/10.1016/j.sedgeo.2005.09.008

Matheny, R.T., 1976, Maya Lowland Hydraulic Systems: Science, 193, 639-646. https://doi. org/10.1126/science.193.4254.639

Matheny, R.T., Gurr, D.L., Forsyth, D.W., Hauck, R., 1983, Investigations at Edzna, Campeche, Mexico: The Hydraulic System: Provo, Utah, USA, Papers of the New World Archaeology Foundation, Brigham Young University Press.

McClain, J., 1997, Tertiary Carbonate Biostratigraphy of Northwestern Yucatan Peninsula, Mexico: DeKalb, IL., USA., Northern Illinois University, M.Sc. Thesis.

Navarro-Olmedo, S., Haenn, N., Schmook, B., Radel, C., 2016, The Legacy of Mexico's Agrarian Counter-Reforms: Reinforcing Social Hierarchies in Calakmul, Campeche: Journal of Agrarian Change, 16 (1), 145167. https://doi.org/10.1111/joac.12095

Norma Oficial Mexicana NOM-127-SSA1-1994, Salud ambiental. Agua para uso y consumo humano. Límites permisibles de calidad y tratamientos a que debe someterse el agua para su potabilización. Diario Oficial Junio, 2000 . 
Pérez-Ceballos, R., Pacheco-Ávila, J., EuanÁvila, J.I., Hernández-Arana, H., 2012, Regionalization based on water chemistry and physicochemical traits in the ring of cenotes, Yucatan, Mexico: Journal of Cave and Karst Studies NationalEspeleological Society, 74, 90102. https://doi.org/10.4311/201 les0222

Perry, E.C., Velazquez-Oliman, G., Marin, L., 2002, The hydrogeochemistry of the karst aquifer system of the northern Yucatan Peninsula, Mexico: International Geology Review, 44(3), 191-221. https://doi. org/10.2747/0020-6814.44.3.191

Perry, E.C., Paytan A., Pedersen, B., VelazquezOliman, G., 2009, Groundwater geochemistry of the Yucatan Peninsula, Mexico: constraints on stratigraphy and hydrogeology: Journal of Hydrogeology, 367, 27-40. https://doi. org/10.1016/j.jhydrol.2008.12.026

Perry, E.C., Velazquez-Oliman, G., Wagner, N., 2011, Groundwater and surface water geochemistry of $\mathrm{Cl}, \mathrm{SO} 4$, and $\mathrm{Sr}$ in Campeche and southern Quintana Roo, in Oswald, Ú. (ed.), Water Research in Mexico: Scarcity, Degradation, Stress, Conflicts, Management and Policy: Berlin, Germany, Springer-Verlag, 87-97.

Peterson, J.A., 1983, Petroleum geology and resources of southeastern Mexico, northern Guatemala, and Belize: Alexandria, VA, USA, U.S. Geological Survey Circular 760.

Pope, K.O., Ocampo, A.G., Fischer, A.G., Vega, F.J., Ames, D.E., King Jr., D.T., Wachtman, R.J., Kletetschka, G., 2005, Chicxulub impact ejecta deposits in southern Quintana Roo, México, and central Belize: Geological Society of America Special Paper 384,171-190. https://doi.org/10.1130/0-8137-2384-1.171

Proceso, 2005, Focos rojos en Calakmul por escasez de agua, id:2092, newspaper report, available at <https://www.proceso.com.mx/225982/ focos-rojos-en-calakmul-por-escasez-deagua>, consulted on May 7th, 2017.
Rosencrantz, E., 1990, Structure and tectonics of the Yucatan Basin, Caribbean Sea, as determined from seismic reflection studies: Tectonics 9(5), 1037-1059. https://doi. org/10.1029/tc009i005p01037

Servicio Geológico Mexicano (SGM), 2017, Carta Geológico-Minera, Estados de: Campeche, Quintana Roo y Yucatán, escala 1:500000: 1 mapa, available at Servicio Geológico Mexicano www.coremisgm.gob.mx - INEGI, consulted on February 15th, 2017. (Update april, 2018 https://www.gob.mx/sgm/ articulos/descarga-las-cartas-impresaseditadas-por-el-sgm-70622? idiom $=\mathrm{es}$ )

Safe Drinking Water Act, 1996, US Environmental Protection Agency, available at < https: / / www. epa.gov/enforcement/safe-drinking-wateract-sdwa-and-federal-facilities\#Summary>, consulted on February 10th, 2017.

Schmitter-Soto. J.J., Comin F.A., EscobarBriones E., Herrera-Silveira J., Alcocer, J., Suarez-Morales E., Elias-Gutierrez M., Diaz-Arce V., Marin L.E. and Steinich B., 2002, Hydrogeochemical and biological characteristics of cenotes in the Yucatan Peninsula (SE Mexico), in: Alcocer, J., Sarma, S.S.S (eds.) ,Advances in Mexican Limnology: Basic and Applied Aspects, Berlin, Germany, Springer-Verlag., 215-228. https://doi. org/10.1007/978-94-010-0415-2_19

Sedov, S., Solleiro-Rebolledo, E., Fedick, S., Pi-Puig, T., Vallejo-Gómez, E., FloresDelgadillo, M.L., 2008, Micromorphology of a Soil Catena in Yucatán: Pedogenesis and Geomorphological Processes in a Tropical Karst Landscape, in Kapur, S., Stoops, G. (eds.), New Trends in Soil Micromorphology: Berlin, Germany, Springer-Verlag. https:// doi.org/10.1007/978-3-540-79134-8_3

Socki, R.A., Romanek, C.S., Perry, E.G., 2002, Stable isotope systematics of two cenotes from the northern Yucatan Peninsula, Mexico: Limnology Oceanography, 47(6), 1808-1818. https://doi.org/10.4319/lo.2002.47.6.1808 
Tankersley, K.B., Dunning, N.P., Scarborough, V.L., Christopher, C.C., Jones, J.G., Lentz, D.L., 2015, Fire and Water: The Archaeological Significance of Tikal's Quaternary Sediments, in Lentz, D.L., Dunning, N.P., Scarborough, V.L. (eds.), Tikal: Paleoecology of an Ancient Maya City, Cambridge University Press, $16-45$.

Tankersley, K., Dunning, N.P., Scarborough, V., Lentz, D., Carr, C., 2016, Catastrophic volcanism and its implication for agriculture in the Maya Lowlands, Journal of Archaeological Science: Reports, 5, 465-470. https://doi. org/10.1016/j.jasrep.2015.12.019
Viniegra-O., F., 1981, Great carbonate bank of Yucatán, southern Mexico: Journal of Petroleum Geology, 3(3), 247-278. https:// doi.org/10.1111/j.1747-5457.1981. tb00930.x

Wagner, N., 2009, A geochemical study of the southern and northeastern Yucatan Peninsula, Mexico: DeKalb, IL., USA., Northern Illinois University, M.Sc. Thesis.

Witschey, W., Brown, C., 2010. EAAMS, the Electronic Atlas of Ancient Maya Sites, available at <http://mayagis.smv.org/index. htm>, consulted on May 19th, 2017. 